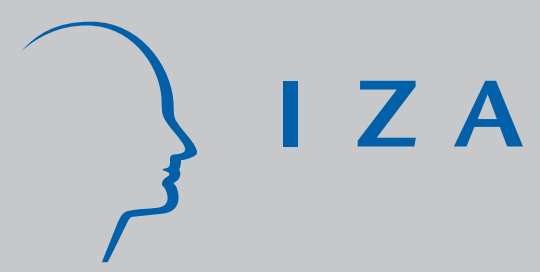

IZA DP No. 659

Defining Unemployment in Developing Countries: Evidence from Trinidad and Tobago

Eric Strobl

David Byrne

December 2002 


\title{
Defining Unemployment in Developing Countries: Evidence from Trinidad and Tobago
}

\author{
Eric Strobl \\ CORE, Catholic University of Louvain \\ and IZA Bonn \\ David Byrne \\ University of Virginia \\ Discussion Paper No. 659 \\ Dezember 2002 \\ IZA \\ P.O. Box 7240 \\ D-53072 Bonn \\ Germany \\ Tel.: +49-228-3894-0 \\ Fax: +49-228-3894-210 \\ Email: iza@iza.org
}

This Discussion Paper is issued within the framework of IZA's research area Labor Markets in Transition Countries. Any opinions expressed here are those of the author(s) and not those of the institute. Research disseminated by IZA may include views on policy, but the institute itself takes no institutional policy positions.

The Institute for the Study of Labor (IZA) in Bonn is a local and virtual international research center and a place of communication between science, politics and business. IZA is an independent, nonprofit limited liability company (Gesellschaft mit beschränkter Haftung) supported by the Deutsche Post AG. The center is associated with the University of Bonn and offers a stimulating research environment through its research networks, research support, and visitors and doctoral programs. IZA engages in (i) original and internationally competitive research in all fields of labor economics, (ii) development of policy concepts, and (iii) dissemination of research results and concepts to the interested public. The current research program deals with (1) mobility and flexibility of labor, (2) internationalization of labor markets, (3) welfare state and labor market, (4) labor markets in transition countries, (5) the future of labor, (6) evaluation of labor market policies and projects and (7) general labor economics.

IZA Discussion Papers often represent preliminary work and are circulated to encourage discussion. Citation of such a paper should account for its provisional character. A revised version may be available on the IZA website (www.iza.org) or directly from the author. 
IZA Discussion Paper No. 659

December 2002

\section{ABSTRACT \\ Defining Unemployment in Developing Countries: Evidence from Trinidad and Tobago*}

The International Labour Organisation (ILO) argues for relaxing the standard definition of unemployment in developing countries by eliminating the requirement that a person be actively searching for a job. We examine whether such an extension of the standard definition is appropriate in the case of Trinidad and Tobago. Specifically, we use the Trinidad and Tobago labour force survey to examine whether active job search is important in determining the labour market transitions of the non-employed. Our results indicate that in Trinidad and Tobago males, who under the standard criteria would be considered out of the labour force because they report willingness to work but are not currently searching for a job, are appropriately classified as unemployed. Further evidence suggests that this may be because job search may not be as meaningful in rural as it is in urban areas.

JEL Classification: J6, O1

Keywords: definition of unemployment, job search, developing countries

Corresponding author:

Eric Strobl

CORE

Université Catholique Louvain

Voie du Roman Pays 34

1348 Louvain-la-Neuve

Belgium

Tel.: +32 10474328

Fax: +32 10474301

Email: strobl@core.ucl.ac.be

\footnotetext{
* Thanks are due to Peter Pariaj and the Trinidad and Tobago CSO for assistance with and provision of data. We are also grateful to Holger Goerg and Frank Walsh for comments on an earlier draft and to Ralph Hussmanns and Constance Sorrentino for advice on various other aspects. All remaining errors are, of course, our own.
} 


\section{Section I - Introduction}

The unemployment rate is the most widely used indicator of the well being of a labour market and an important measure of the state of an economy in general. While the unemployment rate is in theory straightforward to calculate, actually classifying non-employed working age persons as unemployed, rather than out of the labour force, is difficult in practice. To facilitate comparisons of unemployment rates over time and across countries, the International Labour Organisation (ILO) has since 1954 set forth guidelines for this purpose, according to which a person is unemployed if the person is (a) not working, (b) currently available for work, and (c) seeking work. These guidelines have now been adopted, at least in some form, by most developed and some developing countries. ${ }^{1}$

Practical implementation of even these simple ILO guidelines is, however, not without controversy, particularly with respect to the job search criteria. ${ }^{2}$ The objective of the active job search requirement is to identify those non-employed who are "attached" to the labour force, i.e., those who can reasonably expect and will want to work in the near future, by an observable characteristic. Reported current job search serves this purpose well in industrialised countries where the bulk of the population engages in paid full-time employment and information about vacancies is relatively easy to acquire. This may not be the case in many developing countries where there are no clear channels for the exchange of labour market information, particularly given their generally large rural sectors. ${ }^{3}$ In view of this in 1982 the ILO Thirteenth International Conference of Labour Statisticians introduced amplifications with regard to the original ILO

\footnotetext{
${ }^{1}$ See the proceedings of the Eight International Convention of Labour Statisticians (1954).

${ }^{2}$ See, for instance, OECD $(1987,1995)$ and Sorrentino (2000) for a discussion of the controversies involved.
} 
definition of unemployment by allowing for the partial or full relaxation of the active job search requirement in situations "where the conventional means of seeking work are of limited scope, where labour absorption is, at the time, inadequate, or where the labour force is largely selfemployed..." (ILO, 1983, p. xi).

The approach in empirical research on the issue of requiring active job search in defining unemployment has generally focused on comparing individual's labour market transitions over time. However, while this issue is arguably relatively more important for developing countries and a more flexible definition of unemployment has now been adopted by a number of these ${ }^{4}$, the evidence has, except for Kingdon and Knight (2000), been exclusively confined to the developed world. ${ }^{5}$ Moreover, limited to only cross-sectional data for South Africa, Kingdon and Knight (2000) were not able to directly test whether active job search is important in appropriately defining individuals as unemployed in terms of their future labour market status. Instead they use evidence on the higher level of deprivation and the impact of non-searchers on local wage determination as support for employing a more flexible definition of unemployment in South Africa.

In this paper we address the problem of defining unemployment in a developing country context by specifically using a data set for Trinidad and Tobago (T\&T) that allows us to study individual's labour market behaviour over time. T\&T serves as an ideal case study in that since

\footnotetext{
${ }^{3}$ See Hussmanns (1994).

${ }^{4}$ For example, in surveying the definition of unemployment used for the unemployment series published by the ILO we found that out of the 55 developing countries represented 22 used a more flexible definition by either partially or fully relaxing the job search criteria.

${ }^{5}$ The evidence for developed countries, mostly for the US and Canada, has been mixed. See, for instance, Hall (1970), Clark and Summers (1979), Clark and Summers (1982), Flinn and Heckman (1983), Gonül (1992) and, more recently, Jones and Riddell (1999).
} 
the early 1960s it has used a more flexible definition of unemployment than the original stringent ILO criteria by relaxing the active job search requirement under the argument that the latter was not appropriate for its underdeveloped labour market. In T\&T, as in other developing countries, the non-searching, non-employed persons who want to work are non-negligible - for instance, in 1998 their exclusion from the unemployed would have lowered the official unemployment rates for males and females by over three and five percentage points, respectively. ${ }^{6}$

The paper is organised as follows. Section II describes and analyses the definition of unemployment in T\&T. The subsequent section outlines the test of the appropriate definition of unemployment that we employ. In Section IV we use this test on our micro-level panel data set. Finally, concluding remarks are given in the last section.

\section{Section III - T\&T Definition of Unemployment}

As in many developing countries, the official definition of unemployment in T\&T does not require active job search. Specifically, the T\&T Central Statistics Office (CSO) defines the unemployed as not only those non-employed that are active job seekers who want to work, but also includes those non-active job seekers that looked for work during the three month period preceding the interview and who at the time of interview did not have a job but still wanted work. For the remainder of this paper, we refer to this latter group as the 'marginally attached'.

\footnotetext{
${ }^{6}$ Kingdon and Knight (2000) find for South Africa that including all non-searchers that are willing to work increases the total unemployment rate by 15 percentage points in 1997.
} 
Using aggregate statistics published by the T\&T CSO from its labour force survey, the Continuous Sample Survey of Population $(\mathrm{CSSP})^{7}$, we were able to calculate unemployment rates for both the T\&T and the more stringent ILO definition from 1963 onwards. These series are depicted for males and females in Figures 1 and 2, respectively. As can be seen, the two male unemployment rates follow a virtually identical cyclical pattern. The level of the more stringent ILO definition, however, is considerably lower, on average about 3.6 percentage points, than that derived under the T\&T definition, thus suggesting that the 'marginally attached' males are of substantial numbers. Moreover, spearman correlation coefficients between the difference and the levels of the ILO and the T\&T definitions are 0.52 and 0.65 , respectively, and significant at the one per cent level. The probable explanation for this positive correlation is, of course, intuitive - during bad times the probability of finding a job is substantially lower and hence more non-employed persons are discouraged from searching. ${ }^{8}$

\section{[Figures 1 and 2 here]}

The overall trends of the female unemployment rate are, except for the 1970s, similar to that of males. What is strikingly different, however, is the substantially greater difference in the rates of unemployment as defined by the ILO and the T\&T criteria for females. On average, the T\&T definition is 7.2 percentage points higher and has ranged from between 4.1 and 10.3 percentage points. Also, in contrast to males, spearman correlation coefficients of the yearly series do not suggest any correlation, negative or positive, between their levels and difference.

\footnotetext{
${ }^{7}$ The CSSP is a quarterly rotating panel household survey based on a stratified cluster design.

${ }^{8}$ However, it must be noted that this correlation is due to year to year changes and that once the series are converted to three point moving averages the positive correlation is substantially lower and no longer significant.
} 
To gain some insight into how active job seekers differ from the marginally attached, we estimate a set of probits using an indicator for the marginally attached status as the dependent variable on the three years, 1996-98, of micro-level information from the CSSP available to us. We include explanatory variables for age, urban residence, marital status, and educational attainment. We also control for both the presence of children and elderly persons in the household to account for the fact that in T\&T many households also include extended family members. ${ }^{9}$ We first consider all people classified as unemployed under the broader T\&T definition. Results are reported in Table $1 .{ }^{10}$ For males, we find that rural residents are more likely to be marginally attached than urban residents. The younger unemployed and those with at most primary education are also more likely to be marginally attached, although this effect occurs at a decreasing rate. Results for females are qualitatively similar with the exception that the presence of elderly household members increases the probability of being marginally attached and it is secondary education $\mathrm{O}$ levels as the highest educational attainment that matters.

\section{[Table 1 here]}

We next compare the marginally attached to those not in the labour force using a similar specification. Results in Table 1 indicate for men that rural residents are more likely to be marginally attached, as are married and older males, although this latter effect occurs at a decreasing rate. ${ }^{11}$ Additionally, those with greater levels of education are also more likely to be outside of the labour force. Moreover, the presence of elderly persons and small children in

\footnotetext{
${ }^{9}$ All estimations also include year and seasonal dummies.

${ }^{10}$ Children are defined as those less than 14 years of age, while elderly are those older than 70.
} 
the same household significantly increases the probability of a male being classified as marginally attached. Given that males in the fairly traditional T\&T society are likely to be the breadwinners in the household and that the presence of elderly and/or children are likely to exert greater financial strain, it seems intuitive that these household composition variables are linked to male labour force attachment. In contrast to males, household composition variables do not seem to matter for females. In terms of the highest educational level, it is only secondary $\mathrm{O}$ levels that can help predict whether a female is marginally attached rather than out of the labour force, while age, marital status and area of residence have a similar effect as for males.

\section{Section III - Empirical Test}

A natural approach to determine whether the marginally attached should be considered unemployed or out of the labour force, is to compare their transition probabilities to those of these other two labour market states - in other words, to examine whether they are behaviourally similar. This approach was first adopted by Flinn and Heckman (1983) and later extended by, amongst others, Jones and Riddell (1999). Following Jones and Riddell (1999), we utilise a Markov transition model with four states - employed (E), unemployed (U), marginally attached $(\mathrm{M})$, and out of the labour force $(\mathrm{O})$. The unemployed here consist of those who would be classified as unemployed under the ILO definition, while persons who do not search in the reference week but have searched in the last three months and are willing and able to work are classified as $\mathrm{M}$ and the remaining non-employed as $\mathrm{O}$.

\footnotetext{
${ }^{11}$ This age effect may not be surprising given that the out of the labour force category captures a large amount of students and retirees.
} 
Within this Markov model labour market dynamics are given by a $4 \times 4$ transition matrix $\mathbf{P}$ where each element $\mathrm{P}_{\mathrm{ij}}$ represents the probability of a person in state $\mathrm{i}$ becoming moving (or remaining in) state $\mathrm{j}$ by the following period:

$$
\mathbf{P}=\left(\begin{array}{l}
P_{E E} P_{E U} P_{E M} P_{E N} \\
P_{U E} P_{U U} P_{U M} P_{U N} \\
P_{M E} P_{M U} P_{M M} P_{M N} \\
P_{N E} P_{N U} P_{N M} P_{N N}
\end{array}\right)
$$

As Jones and Riddell (1999) note, necessary and sufficient conditions for individuals in $\mathrm{M}$ and $\mathrm{U}$ to be behaviourally equal states are that the probability of transiting from $\mathrm{M}$ to $\mathrm{E}$ equals that of transiting from $\mathrm{U}$ to $\mathrm{E}$ and the probability of moving from $\mathrm{M}$ to $\mathrm{N}$ is identical to that of moving from $\mathrm{U}$ to $\mathrm{N}$ :

$$
\begin{aligned}
& P_{U E}=P_{M E} \\
& P_{U N}=P_{M N}
\end{aligned}
$$

If these conditions jointly hold then individuals that searched within the reference week and those who searched at some time in the previous months exhibit the same transition behaviour.

It may also be the case that among the non-searching non-employed the marginally attached are not behaviourally distinct from those deemed to be out of the labour force. For this to be true the following must hold:

$$
\begin{aligned}
& P_{M E}=P_{N E} \\
& P_{M U}=P_{N U}
\end{aligned}
$$

One should note that those classified as $\mathrm{N}$ consist of both individuals that are willing to work and those that are not, and by grouping these together at this point we are assuming that they 
are a homogenous group, although we do additionally investigate whether this assumption affects our analysis.

\section{Section IV - Results}

In order to implement our empirical test just outlined on our T\&T data we take advantage of the rotational panel nature of the CSSP, where individual households are interviewed three times - one year after the first interview and then one quarter subsequent to the second interview. Specifically, we linked non-disabled individuals between the ages of 14 and 70 between the second and third interviews across surveys, i.e., one quarter apart, for the three years of micro-level data available to us, 1996-98, using the method proposed for the US Current Population Survey by Madrian and Lefgren (1999). ${ }^{12}$ This provides us with linked observations on labour market status of 9,920 females and 9,648 males.

\section{[Table 2 here]}

The average unconditional transition probabilities for males and females for (2) through (4) are given in Table 2. Accordingly, for females $P_{U E}$ and $P_{M E}$ are fairly similar in magnitude, only differing by about 1.7 percentage points. There appears to be a somewhat larger difference in terms of the unconditional transition probabilities to $\mathrm{N}$ from these two states. In investigating how the data supports (4) and (5) for females we find that $P_{M E}$ is substantially higher than $P_{N E}$ and that $P_{M U}$ is noticeably higher than $P_{N U} ; 14.3$ and 12.5 percentage points,

\footnotetext{
${ }^{12}$ The only difference between the identifiers that we use to match individuals and those utilised by Madrian and Lefgren (1999) is a race variable; this information was not available to us.
} 
respectively. We also experimented with excluding from $\mathrm{N}$ those that are unwilling to work (about 23.4 per cent), but found similar results.

Table 2 shows that the differences in the unconditional transition probabilities from $\mathrm{M}$ to either $\mathrm{E}$ or $\mathrm{U}$ compared to those originating from $\mathrm{N}$ are even more pronounced for males, 37.5 percentage points for the former and 20 percentage points for the latter. As with the females, this result was not altered by excluding those not willing to work from N. In examining whether the male $\mathrm{M}$ and $\mathrm{U}$ are behaviourally similar, we firstly find that the transition rates to $\mathrm{N}$ only differ by 7.0 percentage points. In contrast to our female sample, we find that the unconditional probability of becoming employed is higher for $\mathrm{M}$ relative to that arising from $\mathrm{U}$, although only by 5.2 percentage points. Nevertheless, the large differences in the transition rates to $\mathrm{E}$ and $\mathrm{U}$ between men coming from states $\mathrm{M}$ and $\mathrm{N}$ seem to certainly suggest that the men in $\mathrm{M}$ are much more like those in $\mathrm{U}$ than those in $\mathrm{N}$.

Conclusions drawn from unconditional probabilities must be treated with some caution. As was clear from the probit results given in Section III, the male and female $\mathrm{M}$ differ in a number of aspects from their $\mathrm{U}$ and $\mathrm{N}$ counterparts. Thus, to draw more general conclusions regarding behavioural differences between the states, we now condition on observables. Following Jones and Riddell (1999) we first estimate a multinomial logit model of their labour market state transitions to test whether one can pool the individuals originating from $\mathrm{M}$ with those from $\mathrm{U}$. To do this we consider all individuals who occupy the $\mathrm{M}$ or $\mathrm{U}$ state in the first period, so that their three destination states are $\mathrm{N}, \mathrm{E}$, or the joint $\mathrm{M} / \mathrm{U}$ state, i.e., their initial state. The covariates are the same as we used in the probit models. Subsequently we estimate an unrestricted model which includes a dummy variable for those originating in $\mathrm{M}$ and 
interactions of the covariates with this dummy variable. The unrestricted model thus allows for a different intercept and different impacts of the covariates on the transitions for the two origin states in question - in other words, it allows for different transition behaviour for those in $\mathrm{M}$ and U. A likelihood ratio test of the restricted versus the unrestricted model allows us then to test (2) and (3). A similar approach is used to determine whether we can pool $\mathrm{M}$ and $\mathrm{N}$ in terms of their transition probabilities into the appropriate three destination states, i.e., to test (4) and (5).

The results of the likelihood ratio tests of equivalence for (2) and (3) and (4) and (5) for males and females are provided in Table $3 .^{13}$ Accordingly, as indicated by the $\mathrm{p}$-values of the likelihood ratio tests of the multinomial logit models, for males one cannot reject the null of equivalence between $\mathrm{M}$ and $\mathrm{U}$, but can reject the null when one compares the behavioural outcome of those in $\mathrm{M}$ to those in $\mathrm{N}$.

Of course, one of the problems with using the multinomial logit model to test for equivalence in the context here is its strong underlying assumption that there is independence between the possible outcomes (independence of irrelevant alternatives). As a robustness check we thus, as Jones and Riddell (1999), for each equivalence test also test the restrictions (2) through (5) separately using binary logit models. ${ }^{14} \mathrm{P}$-values of the likelihood tests of the binary logit models for each of these, also given in Table 3, however, only confirm our original results. ${ }^{15}$ Thus, we find evidence for males suggesting that including non-active seekers who are

\footnotetext{
${ }^{13}$ Given that our main focus is on the equivalence tests we do not report the full estimates of the model here. Detailed results are available in Byrne and Strobl (2001).

${ }^{14}$ One can roughly view the binary logit models as assuming the opposite extreme, i.e., complete dependence.

${ }^{15}$ In terms of comparing $\mathrm{U}$ and $\mathrm{N}$, we also investigated whether it is the inclusion of many individuals in $\mathrm{N}$ who are not willing to work that is driving the rejection of equivalence of these two states, but found that this did not change our earlier conclusion.
} 
marginally attached, in the sense of being willing to and having looked for work within the last three months, in the unemployment pool is indeed appropriate for $\mathrm{T} \& \mathrm{~T}$ in that they are not behaviourally different from those classified as unemployed under the standard ILO criteria, but are different from those considered not to be part of the labour force.

\section{[Table 3 here]}

Test results for the female sample indicate that females originating in $\mathrm{M}$ are also behaviourally distinct to those originating in $\mathrm{N}^{16}$ In contrast to our male sample, we discover that the female $\mathrm{M}$ are also behaviourally distinct from those in $\mathrm{U}$, as shown by the significance of our multinomial logit likelihood ratio test statistic. This does not seem to rest on the assumptions inherent in using multinomial logit models, as the binary logit results suggest that at least (3) can be rejected. Therefore one may argue that the female working age population should best be classified into four rather than three separate categories.

One of the problems with the above approach is that one is not taking account of the duration of the non-employment spell of individuals. ${ }^{17}$ If there is, however, duration dependence in the conditional probabilities of exiting non-employment, then it is likely to affect both the initial labour market state as well as the transition probabilities. In the most extreme case, the labour market states defined by search behaviour may simply be proxies for the duration of nonemployment experienced by the individual and thus have no independent effect on transition probabilities. For example, the average non-employment durations of those males in U, M and

\footnotetext{
${ }^{16}$ Again, excluding those from $\mathrm{N}$ not willing to work did not alter these results.

${ }^{17}$ This argument was first made by Lemieux (1998).
} 
$\mathrm{N}$ are 12.1, 27.2, and 105.4 months, respectively, while the corresponding numbers for females are 19.9, 31.1, and 130.7 months.

In order to examine whether duration dependence may be driving our results, we reduce our sample to those whose non-employment spell was less 12 months, i.e., we exclude all the long-term unemployed, and repeat the exercise undertaken for the total male and female samples. ${ }^{18}$ One should note that we are thus implicitly assuming that there is no significant duration dependence effect as long as the last time the individual worked was within the last year. Our multinomial and binary logit results for these sub-samples are given in Table 3. Accordingly, we still find for males that those in M, while behaviourally distinct from those in N, are behaviourally similar to those classified as U. In terms of females, we also find that the overall result still holds, i.e., females in $\mathrm{M}$ are behaviourally distinct from those in $\mathrm{U}$ and $\mathrm{N}$.

As argued by Hussmanns et al (1990), one of the reasons why the job search criteria of unemployment may not be as meaningful in developing as it is in developed countries is that channels for the exchange of labour market information in the latter may not exist, may not be widely used, or may be limited to certain urban sectors. Moreover, in developing countries in "rural areas and in agriculture, most workers have more or less complete knowledge of the work opportunities in their areas at particular periods of the year, making it often unnecessary to take active steps to seek work" (Hussmanns et al, 1990, p. 105). In contrast, urban areas in developing countries, especially in the face of institutional rigidities, have developed large informal sectors for which job search are likely to be more meaningful than in rural areas, and

\footnotetext{
${ }^{18}$ Our choice of 12 months rather than some shorter time period was due to sample size considerations.
} 
T\&T is no exception to such a development. ${ }^{19}$ One should also note that earlier we found that in T\&T rural unemployed persons are more likely to be marginally attached than urban unemployed persons.

To investigate this issue we divided our male and female samples into those individuals residing in urban and rural areas in $T \& T .{ }^{20}$ The results of applying our econometric equivalence tests for these sub-samples are also given in Table 3. Accordingly, we find for females that distinguishing between women that reside in urban or rural areas does not alter the result we found for the overall sample. Both multinomial and binary logit tests confirm that non-employed female non-searchers that searched within the last three months are behaviourally different from those in $\mathrm{U}$ and those in $\mathrm{N}$. For males one discovers that search may indeed be more meaningful in urban areas - for this group one can reject the equivalence test both on the basis of the multinomial as well as the binomial logit tests. In contrast, one cannot reject the null of equivalence for males residing in rural areas. Thus, our evidence lends some credence to the argument that search may not be as meaningful in rural areas, although only for males.

\section{Section VI - Concluding Remarks}

Since the early 1980s the ILO has allowed for a more flexible definition of unemployment for developing countries by relaxing the job search criteria under the rationale that job search may not be as meaningful an indicator of labour force attachment in developing

\footnotetext{
${ }^{19}$ See Rambarran (1998).

${ }^{20}$ The urban/rural classification is that used by the T\&T CSO.
} 
as it is in developed countries. In this paper we examine whether such a broader definition of unemployment is appropriate in Trinidad and Tobago.

Our results indicate that males that are currently not searching, but are willing to work and have searched in the last three months, are indeed not behaviourally different from those unemployed that are currently searching for a job, but are different from others out of the labour force. Breaking our male sample into those that live in rural and those that live in urban areas, we find that behavioural similarity to the unemployed can only be upheld for those living in rural areas. This suggests that for the non-employed job search may not be as meaningful or important for men residing in rural areas as it is for those that reside in urban areas. There may be a number of reasons for this, including the seasonality of work, the higher cost of job search, the higher unemployment rate and the remoteness of rural areas. In the case of females, both urban and rural, we can reject the hypothesis that those non-searching non-employed that are willing to work and have searched for a job in the last three months are behaviourally similar to those out of the labour force and the job searching non-employed. One possible explanation for this may be that for many females non-market work may play a more important role in the decision to search. Nevertheless, overall our results for females suggest that the female working age population should perhaps best be classified into four labour market state groups.

On a more general level, our results imply that developing countries should, as has already been recognised by the ILO, be careful in strictly applying the standard ILO definition of unemployment to calculate unemployment rates. Persons who are not searching for a job, but want and are willing to work, are likely to be of substantial numbers and may, in some cases, not be that different in behaviour from the standard unemployed. Excluding these may 
then result in substantially underestimating the true degree of labour market slack in a developing country. Thus, while comparability of unemployment rates across countries certainly requires adoption of common standards, if these standards are stringently applied there may be some trade-off in terms of applicability. 
Table 1: Determinants of the Probability of being Marginally Attached Relative to the Unemployed (Job Seeking) and those Out of the Labour Force

\begin{tabular}{|c|c|c|c|c|}
\hline \multirow{2}{*}{$\begin{array}{l}\text { Comparison } \\
\text { Group: }\end{array}$} & \multicolumn{2}{|c|}{ Unemployed } & \multicolumn{2}{|c|}{ Out of the Labour Force } \\
\hline & Male & Female & Male & Female \\
\hline Urban & $\begin{array}{c}-0.445^{* * * *} \\
(0.074)\end{array}$ & $\begin{array}{c}-0.300^{* * *} \\
(0.065)\end{array}$ & $\begin{array}{c}-0.638 * * * \\
(0.073)\end{array}$ & $\begin{array}{c}-0.212 * * * \\
(0.049)\end{array}$ \\
\hline Marital Status & $\begin{array}{l}-0.035 \\
(0.114)\end{array}$ & $\begin{array}{c}-0.367 * * * \\
(0.103)\end{array}$ & $\begin{array}{c}0.115 \\
(0.095)\end{array}$ & $\begin{array}{c}-0.742 * * * \\
(0.058)\end{array}$ \\
\hline Age & $\begin{array}{c}-0.078 * * * \\
(0.015)\end{array}$ & $\begin{array}{c}0.256^{* * * *} \\
(0.012)\end{array}$ & $\begin{array}{c}-0.103 * * * \\
(0.018)\end{array}$ & $\begin{array}{c}0.078 * * * \\
(0.008)\end{array}$ \\
\hline $\mathrm{Age}^{2}$ & $\begin{array}{c}0.001 * * * \\
(0.000)\end{array}$ & $\begin{array}{c}-0.003 * * * \\
(0.000)\end{array}$ & $\begin{array}{c}0.001 * * * \\
(0.000)\end{array}$ & $\begin{array}{c}-0.001 * * * \\
(0.000)\end{array}$ \\
\hline Primary Ed. & $\begin{array}{c}-0.179^{*} \\
(0.094)\end{array}$ & $\begin{array}{c}-0.351 * * * \\
(0.087)\end{array}$ & $\begin{array}{l}-0.051 \\
(0.100)\end{array}$ & $\begin{array}{c}0.060 \\
(0.060)\end{array}$ \\
\hline $\begin{array}{l}\text { Sec. Ed. } \\
\text { O Levels }\end{array}$ & $\begin{array}{l}-0.152 \\
(0.120)\end{array}$ & $\begin{array}{c}-0.464 * * * \\
(0.111)\end{array}$ & $\begin{array}{l}-0.215^{*} \\
(0.110)\end{array}$ & $\begin{array}{c}0.414 * * * \\
(0.070)\end{array}$ \\
\hline Sec. Ed. & 0.346 & $-0.876 * * *$ & -0.135 & 0.215 \\
\hline A Levels & $(0.349)$ & $(0.219)$ & $(0.262)$ & $(0.172)$ \\
\hline Univ. Ed. & $\begin{array}{l}-0.823 \\
(0.505)\end{array}$ & $\begin{array}{c}-1.634 * * * \\
(0.389)\end{array}$ & $\begin{array}{c}0.073 \\
(0.319)\end{array}$ & $\begin{array}{c}0.159 \\
(0.206)\end{array}$ \\
\hline Children & $\begin{array}{c}0.024 \\
(0.087)\end{array}$ & $\begin{array}{c}0.227 * * * \\
(0.082)\end{array}$ & $\begin{array}{c}0.009 \\
(0.077)\end{array}$ & $\begin{array}{c}0.025 \\
(0.051)\end{array}$ \\
\hline Elderly & $\begin{array}{c}0.027 \\
(0.095)\end{array}$ & $\begin{array}{c}0.325^{* * *} * \\
(0.086)\end{array}$ & $\begin{array}{l}0.207 * \\
(0.108)\end{array}$ & $\begin{array}{c}0.051 \\
(0.068)\end{array}$ \\
\hline $\begin{array}{l}\text { Nobs. } \\
X^{2}(11)\end{array}$ & $\begin{array}{c}1249 \\
90.96 * * *\end{array}$ & $\begin{array}{c}1333 \\
127.90^{* * * *}\end{array}$ & $\begin{array}{c}2628 \\
879.48^{* * * *}\end{array}$ & $\begin{array}{c}5518 \\
513.93 * * *\end{array}$ \\
\hline
\end{tabular}

$1: * * *, *$, and * signify one, five, and ten per cent significance levels, respectively.

2: The dependent variable takes on the value of one when the individual is marginally attached and zero if the individual is in the comparison group.

3: All regressions include year and seasonal dummies.

4. Robust std. errors in parentheses. 
Table 2: Unconditional Transition Probabilities

\begin{tabular}{lcc}
\hline & Male & Female \\
\hline$P_{U E}$ & 0.440 & 0.234 \\
$P_{M E}$ & 0.492 & 0.217 \\
$P_{N E}$ & 0.117 & 0.074 \\
$P_{M U}$ & 0.239 & 0.157 \\
$P_{N U}$ & 0.039 & 0.032 \\
$P_{U N}$ & 0.060 & 0.244 \\
$P_{M N}$ & 0.130 & 0.400 \\
\hline
\end{tabular}

Table 3: Probability Values for Likelihood Ratio Tests of Equivalence

\begin{tabular}{|c|c|c|c|c|c|c|}
\hline \multirow{2}{*}{ TEST: } & \multicolumn{2}{|c|}{ Multinomial Logit Tests } & \multicolumn{4}{|c|}{ Binary Logit Tests } \\
\hline & $\begin{array}{l}P_{U E}=P_{M E} \\
P_{U N}=P_{M N}\end{array}$ & $\begin{array}{l}P_{M E}=P_{N E} \\
P_{M U}=P_{N U}\end{array}$ & $P_{U E}=P_{M E}$ & $P_{U N}=P_{M N}$ & $P_{M E}=P_{N E}$ & $P_{M U}=P_{N U}$ \\
\hline & \multicolumn{6}{|c|}{ Total Sample } \\
\hline Male & 0.274 & 0.000 & 0.118 & 0.349 & 0.000 & 0.000 \\
\hline \multirow{2}{*}{ Female } & 0.068 & 0.000 & 0.360 & 0.009 & 0.000 & 0.000 \\
\hline & \multicolumn{6}{|c|}{ Short-Term Non-Employed (Less than 12 Months) } \\
\hline Male & 0.227 & 0.000 & 0.158 & 0.120 & 0.001 & 0.017 \\
\hline \multirow[t]{2}{*}{ Female } & 0.001 & 0.000 & 0.689 & 0.060 & 0.004 & 0.111 \\
\hline & \multicolumn{6}{|c|}{ Urban } \\
\hline Male & 0.045 & 0.000 & 0.293 & 0.014 & 0.000 & 0.012 \\
\hline \multirow[t]{2}{*}{ Female } & 0.004 & 0.005 & 0.046 & 0.010 & 0.002 & 0.061 \\
\hline & \multicolumn{6}{|c|}{ Rural } \\
\hline Male & 0.520 & 0.000 & 0.549 & 0.652 & 0.000 & 0.000 \\
\hline Female & 0.026 & 0.000 & 0.251 & 0.041 & 0.000 & 0.000 \\
\hline
\end{tabular}


Figure 1: Male Unemployment Rate 1963-97

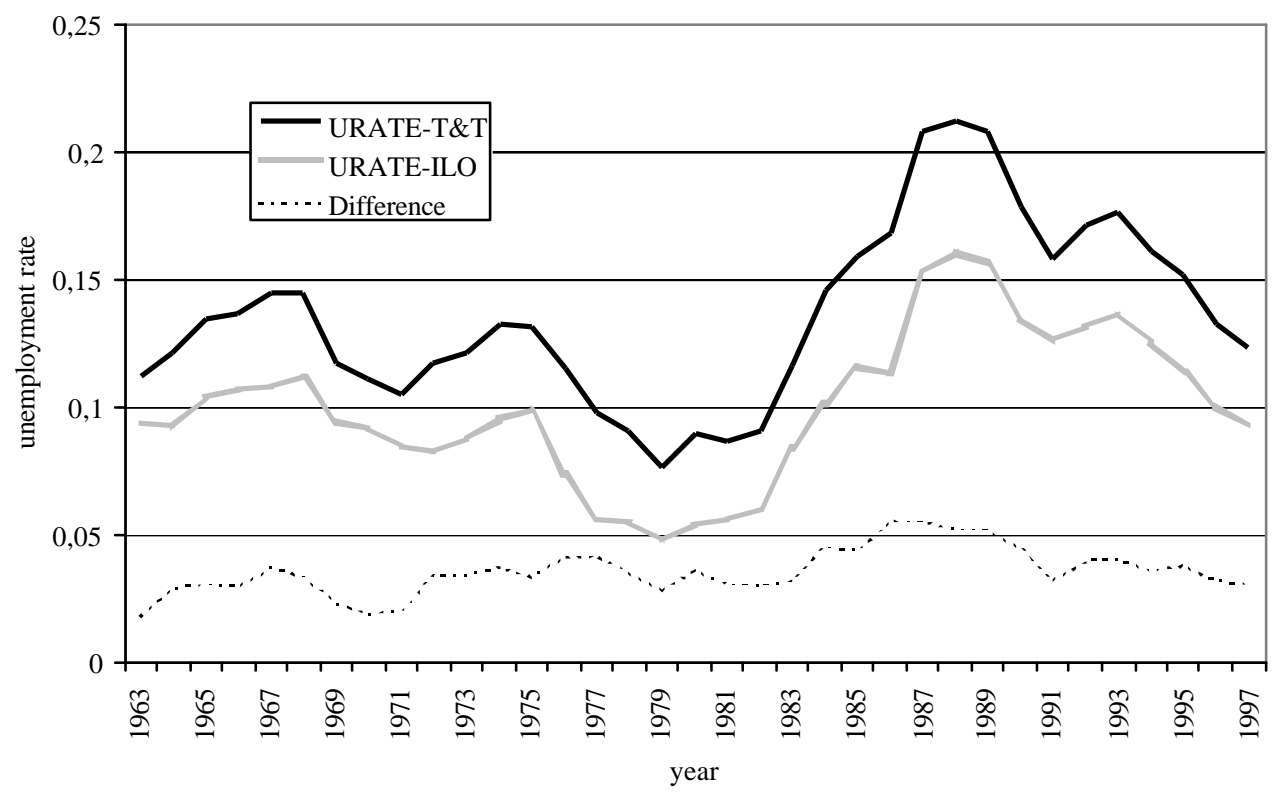

Figure 2: Female Unemployment Rate 1963-97

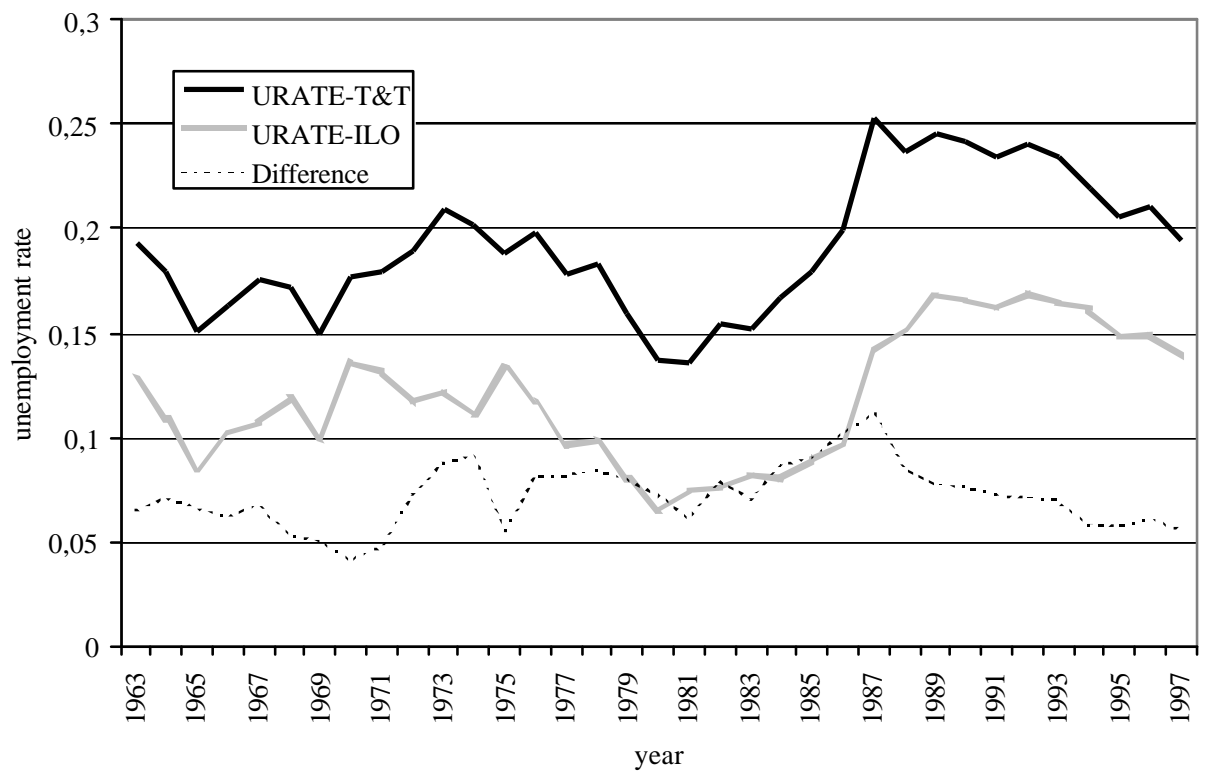




\section{References}

Byrne, D. and Strobl, E. (2001). "Defining Unemployment in Developing Countries: The Case of Trinidad and Tobago", CREDIT (Nottingham) Working Paper, 01/09.

Clark, K. and Summers, L. H. (1979). "Labor Market Dynamics and Unemployment: A Reconsideration”, Brookings Papers on Economic Activity, 1979: 1, pp. 13-60.

Clark, K. and Summers, L. H. (1982). "The Dynamics of Youth Unemployment", in The Youth Labour Market Problem: Its Nature, Causes and Consequences, ed. R. Freeman and D. Wise, pp. 199-234. University of Chicago Press: Chicago.

CSO (various issues). CSSP: Labour Force Report, Republic of Trinidad and Tobago Ministry of Planning and Development Central Statistics Office: Port of Spain.

Flinn, C. J. and Heckmann, J. J. (1983). "Are Unemployment and Out of the Labor Force Behaviourally Distinct Labor Market States?”, Journal of Labor Economics, 1, pp. 28-42.

Gonul, F. (1992). "New Evidence on Whether Unemployment and Out of the Labor Force are Distinct States", Journal of Human Resources, 27, pp. 329-361.

Hall, R. E. (1970). "Why is the Unemployment Rate So High at Full Employment?", Brookings Papers on Economic Activity, 1970: 3, pp. 369-402.

Hussmanns, R., Mehran, F. and Verma, V. (1990). Surveys of Economically Active Population, Employment, Unemployment and Underemployment: An ILO Manual on Concepts and Methods, ILO: Geneva.

Hussmanns, R. (1994). "International Standards on the Measurement of Economic Activity, Employment, Unemployment and Underemployment”, Bulletin of Labour Statistics, ILO, Geneva, 1994-4, pp. .

ILO (1983). "Thirteenth International Conference of Labour Statisticians, Resolution Concerning Statistics of the Economically Active Population, Employment, Unemployment and Underemployment", Bulletin of Labour Statistics, ILO, Geneva, 1983-3, pp. xi-Xv.

ILO (1990). Statistical Sources and Methods. Vol. 3, Economically Active Population, Employment, Hours of Work (Household Surveys), Geneva.

ILO (1998). 'Unemployment”, Bulletin of Labour Statistics, ILO, Geneva, 1998-3, pp. $52-54$ 
Jones, S. R. G. and Riddell, W. C. (1999). "The Measurement of Unemployment: An Empirical Approach", Econometrica, 67, pp. 147-162.

Kingdon, G. and Knight, J. (2000). "Are Searching and Non-Searching Unemployment Distinct States when Unemployment is High? The Case of South Africa", The Centre of African Economies Working Paper Series, 2000/2.

Lemieux, T. (1998). "Comment”, in Labor Statistics Measurement Issues, eds. Haltiwanger, J. and Marylin, E., pp. 152-155, University of Chicago Press: Chicago.

Madrian, B. C. and Lefgren, L. J. (1999). "A Note on Longitudinallly Matching Current Population Survey (CPS) Respondents”, NBER Technical Working Paper 247.

OECD (1987). "On the Margin of the Labour Force: An Analysis of Discouraged Workers and other Non-Participation”, Employment Outlook, September, pp. 142-170.

OECD (1995). “Supplementary Measures of Labour Market Slack”, Employment Outlook, July, pp. 43-97.

Rambarran, A. (1998). "Labor Market Adjustment in an Oil-Based Econommy: The Experience of Trinidad and Tobago", in Economic Liberalisation and Labour Markets, eds. P. Dabir-Alai, P. and Odekon, M., pp. 197-223; Greenwood Press.

Sorrentino, C. (2000). "International Unemployment Rates: How Comparable are They?", Monthly Labour Review, 2000, November, pp. 1-20. 


\section{IZA Discussion Papers}

\begin{tabular}{|c|c|c|c|c|}
\hline No. & Author(s) & Title & Area & Date \\
\hline 643 & $\begin{array}{l}\text { A. Björklund } \\
\text { M. Sundström }\end{array}$ & $\begin{array}{l}\text { Parental Separation and Children's Educational } \\
\text { Attainment: A Siblings Approach }\end{array}$ & 6 & $11 / 02$ \\
\hline 644 & $\begin{array}{l}\text { J. D. Brown } \\
\text { J. S. Earle }\end{array}$ & $\begin{array}{l}\text { Job Reallocation and Productivity Growth Under } \\
\text { Alternative Economic Systems and Policies: } \\
\text { Evidence from the Soviet Transition }\end{array}$ & 4 & $11 / 02$ \\
\hline 645 & $\begin{array}{l}\text { M. Karanassou } \\
\text { H. Sala } \\
\text { D. J. Snower }\end{array}$ & $\begin{array}{l}\text { Long-Run Inflation-Unemployment Dynamics: } \\
\text { The Spanish Phillips Curve and Economic Policy }\end{array}$ & 3 & $11 / 02$ \\
\hline 646 & $\begin{array}{l}\text { L. Graham } \\
\text { D. Snower }\end{array}$ & The Return of the Long-Run Phillips Curve & 3 & $11 / 02$ \\
\hline 647 & $\begin{array}{l}\text { C. Grund } \\
\text { D. Sliwka }\end{array}$ & Envy and Compassion in Tournaments & 1 & $11 / 02$ \\
\hline 648 & $\begin{array}{l}\text { C. Schnabel } \\
\text { T. Schank } \\
\text { J. Wagner }\end{array}$ & $\begin{array}{l}\text { Works Councils - Sand or Grease in the } \\
\text { Operation of German Firms? }\end{array}$ & 3 & $11 / 02$ \\
\hline 649 & $\begin{array}{l}\text { J. van Ours } \\
\text { J. Veenman }\end{array}$ & $\begin{array}{l}\text { From Parent to Child: Early Labor Market } \\
\text { Experiences of Second-Generation Immigrants } \\
\text { in the Netherlands }\end{array}$ & 1 & $11 / 02$ \\
\hline 650 & $\begin{array}{l}\text { H. Battu } \\
\text { P. J. Sloane }\end{array}$ & Overeducation and Ethnic Minorities in Britain & 2 & $11 / 02$ \\
\hline 651 & E. Schlicht & $\begin{array}{l}\text { Social Evolution, Corporate Culture, and } \\
\text { Exploitation }\end{array}$ & 3 & $11 / 02$ \\
\hline 652 & E. Plug & $\begin{array}{l}\text { How Do Parents Raise the Educational } \\
\text { Attainment of Future Generations? }\end{array}$ & 5 & $11 / 02$ \\
\hline 653 & $\begin{array}{l}\text { W. Groot } \\
\text { E. Plug } \\
\text { H. Maassen van den } \\
\text { Brink }\end{array}$ & $\begin{array}{l}\text { Money for Health: The Compensating Variation } \\
\text { of Cardiovascular Diseases }\end{array}$ & 6 & $11 / 02$ \\
\hline 654 & $\begin{array}{l}\text { C. Ruhm } \\
\text { U. G. Gerdtham }\end{array}$ & $\begin{array}{l}\text { Deaths Rise in Good Economic Times: Evidence } \\
\text { From the OECD }\end{array}$ & 2 & $11 / 02$ \\
\hline 655 & $\begin{array}{l}\text { W. Arulampalam } \\
\text { R. A. Naylor } \\
\text { J. P. Smith }\end{array}$ & $\begin{array}{l}\text { Effects of In-Class Variation and Student Rank } \\
\text { on the Probability of Withdrawal: Cross-Section } \\
\text { and Time-Series Analysis for UK University } \\
\text { Students }\end{array}$ & 2 & $11 / 02$ \\
\hline 656 & $\begin{array}{l}\text { T. Beissinger } \\
\text { O. Büsse }\end{array}$ & $\begin{array}{l}\text { The Impact of the Unemployment Benefit } \\
\text { System on International Spillover Effects }\end{array}$ & 2 & $11 / 02$ \\
\hline 657 & $\begin{array}{l}\text { A. Kugler } \\
\text { J. F. Jimeno } \\
\text { V. Hernanz }\end{array}$ & $\begin{array}{l}\text { Employment Consequences of Restrictive } \\
\text { Permanent Contracts: Evidence from Spanish } \\
\text { Labor Market Reforms }\end{array}$ & 2 & $11 / 02$ \\
\hline 658 & $\begin{array}{l}\text { G. Brunello } \\
\text { R. Winter-Ebmer }\end{array}$ & $\begin{array}{l}\text { Why Do Students Expect to Stay Longer in } \\
\text { College? Evidence from Europe }\end{array}$ & 5 & $12 / 02$ \\
\hline 659 & $\begin{array}{l}\text { D. Byrne } \\
\text { E. Strobl }\end{array}$ & $\begin{array}{l}\text { Defining Unemployment in Developing } \\
\text { Countries: Evidence from Trinidad and Tobago }\end{array}$ & 4 & $12 / 02$ \\
\hline
\end{tabular}

An updated list of IZA Discussion Papers is available on the center's homepage www.iza.org. 